\title{
DEVELOPING CASE-BASED LEARNING ORIENTED BIOLOGY MODULE TO IMPROVE SENIOR HIGH SCHOOL STUDENTS' CRITICAL THINKING SKILL
}

\author{
Arnyana, I. B. $\mathrm{P}^{1}$, Upadianti, L.P.E ${ }^{1}$, Suma, $\mathrm{K}^{1}$. \\ ${ }^{1,2,3}$ Program Studi Pendidikan IPA, Program Pascasarjana \\ Universitas Pendidikan Ganesha \\ Singaraja, Indonesia \\ 19usarnyana@yahoo.co.id, ${ }^{2}$ upadiantiemitha@yahoo.co.id, \\ ${ }^{3}$ sumaketut@ymail.com
}

\begin{abstract}
This study aimed to develop and validate the Case-based Learning module to improve the critical thinking skills of high school students. The development model used was the 4-D model that includes, define, design, develope, and disseminate. Module validation was conducted through validity test, practicability test, and effectiveness test which revealed that the module developed has a very high validity with an average score of 4.25 with a very high practicality with an average score of 4.21, and it has the effectiveness to improve critical thinking skills with an average value of the critical thinking skill test of 85.92. Result of $t$ test get $t$ value $22,567>t$ table $(1,868)$ which means that there is a significant improvement of critical thinking skill of students after the implementation of the module. Thus, the module developed is valid, practical, and effective to improve critical thinking skill of high school student.
\end{abstract}

Keywords - learning module, case-based learning, critical thinking skills

\section{INTRODUCTION}

Indonesian Government is faced with the low quality of education and mastery of science. An ideal learning process is designed to teach students as learning subjects with students' activity as its orientation to gain learning achievement in the form of proportional combination of cognitive, affective, and psychomotor. The teaching and learning of science at schools is supposed to involve attitude, process, product, and aplication aspects, so the students can experience an holistic learning process, understanding natural phenomena through problem solving activities, scientific method, and adapt scientific way to find new fact. Moreover, the recent trend in science learning is students are only introduced Biology as product, memorizing concept, theory, principles, with memory as its orientation.

The Program for International Student Assessment (PISA) in 2015 reveals that Indonesia was in the $69^{\text {th }}$ out of 76 countries in the field of Science and Math. While, the Trends in International Mathematics and Science Study (TIMSS), shows that Indonesian students are in the $36^{\text {th }}$ place out of 49 countries in terms of doing scientific procedure. In the last 10 years, PISA and TIMSS show almost similar result.

Some factors are responsible in determining the quality of students' learning achievement in science. One of those factors is learning material. Based on the result of in-depth interview with one of the Biology teachers and students in eleventh grade of SMAN 1 Tabanan, learning materials used in the school were in the form of reference book and student worksheet. Exercises provided in the students worksheet were only intended to make students to copy information from their reference book, which lead to students' low level of understanding to the material. The same phenomena could also be found in several other schools such as SMA N 2 Tabanan, SMA N 1 Kediri, and SMA N 3 Singaraja.

In order to optimize the learning quality, teacher should make innovation in the learning process. Turer and Kunt (2015) stated that a creative teacher has big role in creating an optimal and long term learning on science [1]. One of the innovation is developing learning module. Learning module has more complete material and the instruction was also more focused than the regular textbook. By using module, students can practice their independence and reasoning ability. The module includes synchronized materials completed with project assignment as a facility to encourage students' participation in the learning process.

To overcome the problem on explaining abstract concept, module can be used as the learning resource because it contains illustration and more practical instruction. By giving cases, it is expected that the mudule can help students to understand abstract concept through the illustration and pictures.

Based on the prior observation, the use of module in SMA N 1 Tabanan was limited due to the lack module developed by the teacher in teaching Biology, especially for grade eleventh.

Based on above background, the researcher conduct a study entitled Developing Case-based learning Oriented Module to Improve Students' Critical Thinking in Senior High School. In 
this study, the developed module was integrated with Casebased Learning (CBL) model, in which the students were expected to improve their thinking skill by solving real life related problems related. Case-based learning oriented cases provided in the module should be well-structured. Furthermore, Frederiksen (1984) proposed a well-structured scenario that covers various problems with clearly formulated and completed with formula to test the appropriateness of the answer [2]. This scenario is diference with the scenario of Problem Based Learning which is more ill-structured. The differences between well-structured and ill-structured problem can be seen the Table 1 [2].

TABLE 1. DIFFERENCES BETWEEN WELL-STRUCTURED AND ILLSTRUCTURED PROBLEM

\begin{tabular}{|l|l|}
\hline Ill-structured Problem & Well-structured problem \\
\hline $\begin{array}{l}\text { 1. The objectives are clear but } \\
\text { hidden. }\end{array}$ & $\begin{array}{l}\text { 1. Clear objectives } \\
\text { 2. All information needed } \\
\text { are in the frame of } \\
\text { 2. Unclear information needed } \\
\text { to solve problem }\end{array}$ \\
$\begin{array}{l}\text { 3. Unexpected solution which } \\
\text { leads to unconsistency of } \\
\text { concept. }\end{array}$ & $\begin{array}{l}\text { 3. Consistent concept to } \\
\text { solve the problem. }\end{array}$ \\
\hline
\end{tabular}

Case-based learning contains some cycles: Retrieve, Reuse, Revise and Retain [3]. The cycles of Case-based learning can be seen in Diagram 1.

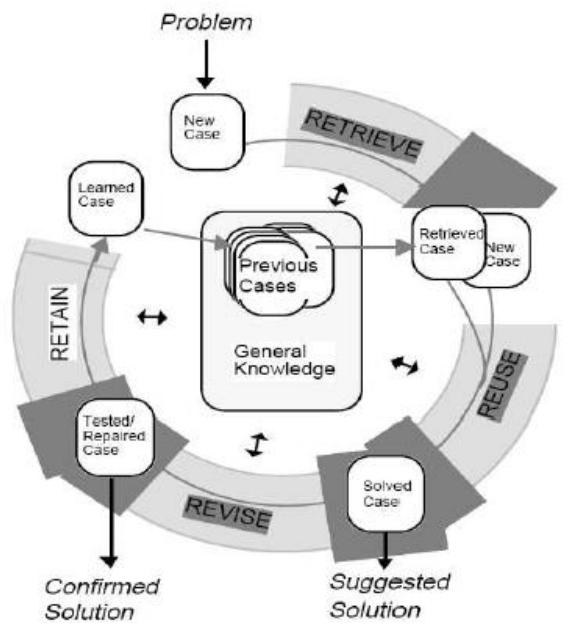

Diagram 1. Cycles on Cased-Based Learning

In the Diagram 1, the problem should be explored in retrieve cycle which then being reused in the discussion within the groups. The following cycle which is revise gives opportunity for the students explain their solution on the problem. At the end of the cycle, students are instructed to draw conclusion for the whole issues being discussed.

While Wood and Anderson had done study on Case-based Learning and revealed that the case-based learning method could improve teachers' skill in giving question effectively because cases could give opportunity for the teachers to think based on the reality [4]. In addition, Rybarczyk et al had stated that the use of case-based learning was very comprehensive with other learning objectives such as minimalize students' understanding and improving students' learning motivation [5].

\section{METHOD}

This development research used 4-D model proposed by Tiagarajan (1974), which consists of four phases: (1) define; (2) design; (3) develop; (4) disseminate [6].

In the first phase, the researcher defined the need and potential of the existence of module in the senior high school, especially related to the critical thinking skill in the eleventh grade students. The need and potential analyzed in the first phase were used as the basic information in designing the module to determine content involved in the module as well as the level of knowledge presented. The determination of the level of knowledge presented in the module was a crucial issue since the module should met students' characteristics.

The phase of developing module which was the third phase was done by using the design from the previous phase. The elaboration of topics and practical instruction included in the module were adjusted with students' characteristics, school facilities, syllabus, and time allocation for Biology subject in the eleventh grade. After developing the module, the researcher proceeded to the next phase which was disseminating. The dissemination was done through expert judgment and field test.

The developed learning module was tested through three stages, namely validity test, practicality test, and effectiveness test. Validity test was done for its content and construction. The validity test contained of three stages which were: (1) count the average score given by each validator; (2) count total score from the average scores; (3) convert the total score into qualitative score based on criteria that can be seen in Table 2 [7].

TABLE 2. VALIDITY CRITERIA FOR LEARNING MODULE

\begin{tabular}{|c|c|c|}
\hline Score & Score Interval & Category \\
\hline 5 & $4,21 \leq \mathrm{Sr} \leq 5,00$ & Very valid \\
\hline 4 & $3,41 \leq \mathrm{Sr} \leq 4,20$ & Valid \\
\hline 3 & $2,61 \leq \mathrm{Sr} \leq 3,40$ & Valid Enough \\
\hline 2 & $1,81 \leq \mathrm{Sr} \leq 2,60$ & Not valid \\
\hline 1 & $1,0 \leq \mathrm{Sr} \leq 1,80$ & Very Not valid \\
\hline
\end{tabular}

While the practicality test was aimed to measure its implementation by students and teachers in the classroom, 
which was done through questionnaires for both the students and the teachers.

Effectiveness test was done through pre-experiment technique by conducting One Group Pre-test Post-test Design. Before conducting effectiveness test, the researcher had conducted test to measure students' level of critical thinking.

The subject of this study were Biology teachers, and 38 eleventh grade students of IPA 7 in SMA N 1 Tabanan in the academic year 2016/2017. There were 10 teachers/practitioners and experts involved in this study, consisted of 2 experts and 8 teachers/practitioners. The object of this research was the learning module.

\section{RESULT AND DISCUSSION}

Development research 4-D model proposed by Tiagaran consists of four phase: define, design, develop, and disseminate [6]. In this study, the researcher only conducted three phases which were define, design, and develop, while the last phase which was disseminate, was not conducted due to the limitation on given time.

In the first phase, the researcher defined learning requirements and analyze the learning objectives. There were five stages which were done in defining phase: (1) analyzing problems found in the school and curriculum, (2) analyzing students' characteristics, (3) material analysis, (4) instruction analysis, (5) specification of learning objectives.

The second phase was designing the module. The developed case-based learning oriented Biology module was referring to the core competency in the 2013 curriculum. The format of the module was also determined in this phase, in which the instruction for practical assignment used case-based learning model, which consisted of retrieving, reusing, revising, and retaining.

The third phase which was developing module resulted in module draft, validated and revised evaluation instrument based on the review from the experts. The phase of developing module included validation process from expert judgment and field test. Before conducting field test of the developed module, its instruments were tested by expert judgments to measure its validity. The experts consisted of two lecturers. The result of instrument validation can be seen in the Table 3 .

The result of instrument validity presented in Table 1 showed that the quality of the developed instrument was categorized as relevan, in which the score was within interval 0,81-1,00.

After gaining the result of instrument validity, the researcher conducted validity test which was done through two parts, expert validation and empirical validation. The empirical validation was done by the Biology lecturers and teachers. Table 4 showed the result of validity test for the developed learning module. The test was done to measure both content and construct validity. The average score of the validity was 4.25 , which was categorized as valid. Thus, the developed module is qualified to be implemented even though there were several suggestions for the improvement of the module.
TABLE 3. ThE RESUlt OF INTSRUMENT VALIDITY TEST

\begin{tabular}{|c|l|c|c|c|c|}
\hline \multirow{2}{*}{$\begin{array}{l}\text { N } \\
\text { o }\end{array}$} & \multicolumn{1}{|c|}{$\begin{array}{l}\text { Research } \\
\text { Instrument }\end{array}$} & \multicolumn{3}{|c|}{ Score } \\
\cline { 3 - 6 } & \multicolumn{2}{|c|}{ Validator 1 } & \multicolumn{2}{c|}{ Validator 2 } \\
\cline { 2 - 6 } 1 & $\begin{array}{l}\text { KVG } \\
\text { Validation } \\
\text { sheet (Module } \\
\text { and Evaluation } \\
\text { Instrument) }\end{array}$ & 0,81 & Relevan & 0,81 & Relevan \\
\hline 2 & $\begin{array}{l}\text { Response of } \\
\text { teacher } \\
\text { quietionaire } \\
\text { toward } \\
\text { learning } \\
\text { module }\end{array}$ & 0,94 & Relevan & 0,94 & Relevan \\
\hline 3 & $\begin{array}{l}\text { Response of } \\
\text { teacher } \\
\text { quietionaire } \\
\text { toward } \\
\text { learning } \\
\text { module }\end{array}$ & 1 & Relevan & 1 & Relevan \\
\hline
\end{tabular}

Valid learning module was achieved because there is conformity between its components and the indicator of validity instruments. The validity instruments were revised to meet experts' standard before being tested in the validity test. Content validity of the developed module showed that the module has met the content standard based on the theory underlying the research. This finding is in line with research done by Wijaya (2015) who states that module development based on the theories can be categorized as valid [8].

TABLE 4. The Result OF MOdULE's VALIDITy Test

\begin{tabular}{|c|c|c|}
\hline Inspected aspects & Validity Result & Criteria \\
\hline Content & 4,1 & Very valid \\
\hline $\begin{array}{c}\text { Evaluation } \\
\text { instruments }\end{array}$ & 4,4 & Very valid \\
\hline Average Score & 4,25 & Very valid \\
\hline
\end{tabular}

Construct validity of the developed module can be viewed from the link among materials in the developed learning module. Each material includes characteristic to stimulate critical thinking skill. These factors determine the quality of the learning module, so it can be implemented in the real teaching and learning process.

Moreover, the practicality of the developed module can be viewed from several indicators, namely; (1) feasibility of the module; (2) teachers' attitude toward the learning module; and (3) students' attitude toward the learning module. The result of practicality test of the developed module can be seen in the Table 5. 
TABle 5. Result Of Module's Practicality

\begin{tabular}{|c|c|c|}
\hline & Score & Category \\
\hline Feasibility & 4,25 & Very Practical \\
\hline Teachers' Attitude & 4,30 & Very Practical \\
\hline Students' Attitude & 4,12 & Practical \\
\hline
\end{tabular}

The practicality test result showed that the developed learning module's orientation on the case-based learning was in practical category. The feasibility score of the developed learning module was 4.25 which was categorized as practical. While the teachers' attitude on its feasibility was 4.30 , and the students' attitude toward the used of the developed module was scored 4.12, both scores were categorized as practical.

These good results were attained because of some reasons. For example, the module was completed with the practical guide, sufficient materials, as well as the appropriate evaluation instruments to assess students' level of competency. It can be said as improvement since there are very few textbook or students' worksheet that can fulfill students" need. In the development of the learning module, the researcher tried to complete all the needed sources and materials to meet students' need.

The effectiveness of the developed module can be seen from the improvement of the average score of pre-test and post-test. The result of pre-test and post-test can be seen in the Table 6 and Table 7.

Table 6. Result of Pre-Test For Students' Critical thinking Test

\begin{tabular}{|l|c|l|}
\hline \multicolumn{1}{|c|}{ Competencies } & Average Score & Categories \\
\hline $\begin{array}{l}\text { Giving simple } \\
\text { explanation }\end{array}$ & 80,5 & Critical \\
\hline Formulating Questions & 82,5 & Very Critical \\
\hline Giving Arguments & 79,5 & Critical \\
\hline Analyzing Problems & 63,5 & Critical \\
\hline Concluding & 72,0 & Critical \\
\hline Evaluating & 80,0 & Critical \\
\hline Determining Action & 85,5 & Very Critical \\
\hline Total Average & $\mathbf{7 7 , 6 4}$ & Citical \\
\hline
\end{tabular}

While in the post-test, there were significant improvement on the result of students' score, as can be seen in the Table 7.

TABle 7. Result of PRE-Test For StUdents' CRitical thinking Test

\begin{tabular}{|l|c|l|}
\hline \multicolumn{1}{|c|}{ Competencies } & $\begin{array}{c}\text { Average } \\
\text { Score }\end{array}$ & Categories \\
\hline $\begin{array}{l}\text { Giving simple } \\
\text { explanation }\end{array}$ & 90,5 & Very Critical \\
\hline Formulating Questions & 92,5 & Very Critical \\
\hline Giving Arguments & 87,5 & Very Critical \\
\hline Analyzing Problems & 80,5 & Critical \\
\hline Concluding & 81,5 & Very Critical \\
\hline Evaluating & 84,75 & Very Critical \\
\hline Determining Action & 89,5 & Very Critical \\
\hline
\end{tabular}

\begin{tabular}{|l|c|l|}
\hline Total Average & $\mathbf{8 6 , 6 8}$ & $\begin{array}{l}\text { Very } \\
\text { Critical }\end{array}$ \\
\hline
\end{tabular}

In pre-test, the gained average score was 77,64 , while in post-test, it increased into 86.68 . Viewing from the minimum passing grade criteria which was 75 , the post-test score was categorized as passed. Statistic test by using t-test with correlation sample shows that calculated t-score $(-22,57)<\mathrm{t}$ table $(-1,868)$. It shows that the developed learning module is effective in improving students' critical thinking skill, and it means that the hypothesis was accepted. Thereby, the casebased learning oriented module for Biology is effective to improve the critical thinking skill of senior high school students.

Although there was learning improvement on the second meeting of the module implementation, there were still some obstacles detected. First, in formulating questions to be discussed, some groups had not referred the revealed cases. Second, there were still some inactive members within each group; (3) most students were unable to effectively spend their time so they could not perform their best on their report.

Some obstacles found in the second meeting were used as evaluation and reflection by the researcher and the teachers so it can be avoided in the next meeting. The result of evaluation and reflection from the second meeting are as follow. First, teacher should give guidance in formulating problems so it referred to the given issue. Second, teacher should approach the students with low participation and motivate them after the reason of their lack of participation is identified. Third, in every session of teaching activity, teacher should remind the students about the time allocation. If it does not work and the allocated time is still not sufficient to accomplish the task, then teacher should modify the instructions, for example by assigning the task as group assignment where students are assigned different roles within their respective groups.

The result of evaluation and solution of the obstacles faced in the second meeting was implemented in the third meeting with the topic "Human Excretion System (Skin)". Generally, the process of learning in this meeting was better than before. The students were getting used to use the developed learning module, to formulate question based on the given issue, to participate better in the discussion session, and to accomplish the task more effectively and efficiently within the allocated time.

In the fourth and fifth meetings, the learning process appeared to be more interesting because in these meetings, students were given opportunity to explore their knowledge to identify various kind of diseases related to excretion (skin). There were also videos played as teaching aid to give visual examples of serious diseases related to excretion (skin). In the fifth meeting, the students were able to memorize the material to be presented and to comment critically and confidently on the given cases and confidently expressed it in front of their friends. The teaching atmosphere also tended to be more conducive since teacher was no longer the center of teaching learning process. There was positive interaction between 
teacher and students, as well as among students. Teacher's role as facilitator could be clearly seen as the teacher listened to and observed the students who were actively referring to the issue and material with their friends. Teacher's role was mainly to confirm on the students' understanding.

In the sixth meeting, the researcher conducted a valid and reliable critical thinking test. It was found out that there was significant progress on the use of the developed learning module reflected on the improvement of average score given by the observer from the first meeting until the last. In the first meeting, the average score was 3,7, categorized as practical. The average score was improved in the second meeting into 4,0 , while it was 4,1 in the third meeting, and 4,4 in the fourth meeting in a very practical category.

The effectiveness of the developed learning module can be seen from the gap between students' score of critical thinking tests conducted in the beginning and end of the module implementation. The average score of the critical thinking test resulted in the end of the meeting was 86,68 , categorized as passed because it was higher than the school passing grade which was 75 . This result shows that there was significant improvement on the students' level of critical thinking since the previous score of the same test was only 77,64. This finding was strengthened by the result of t-test, with $\mathrm{t}$-score $(22,567)>\mathrm{t}$ table $(1,868)$. From these findings, it can be concluded that there was significant improvement on students' critical thinking before and after the use of the developed learning module.

The finding of this study was relevant with the findings of the study done by Susandari (2012). Susandari (2012) in her study about the influence of case-based on the students' understanding toward concept and education theories in Universitas Islam Bandung, found that the students could comprehend psychological concept and theory based on case better than using other learning method like presentation and discussion [9]. It is related to the characteristics of case-based learning method that presenting such as well-structures case to construct a more guided discussion session.

In addition, all critical thinking skill spectrum was generally revealed within the process of learning through the use of the developed module. However, the test result shows that the module mostly encouraged students to train their skills on formulating problems, giving argument, and drawing conclusion. More specifically, students' skill in giving argument was stimulated when they were given cases to investigate. While students' skill on formulating problems was fostered to explore questions to be answered through experiment. In the model of case-based learning, both of those skills appeared in the phase of retrieving. Furthermore, skill for drawing conclusion was trained during the phase of retaining, in which the students were asked to conclude and comprehend the result of solving problem as well as relate it to the learning material.

The effectiveness of developed learning module, in improving students' critical thinking was caused by some factors such as the use of health cases that should be criticized by the students. Moreover, the developed module had been adjusted to the 2013 curriculum used in SMA Negeri 1 Tabanan with scientific approach as the characteristics of the curriculum. It was in line with the case-based learning syntax which contained learning procedures with scientific approach. Moreover, students were given opportunity to test the impact of certain problems to make them always seek clarification on every issue they find in their real life. Through that way, students are expected to analyze things from different point of views before making judgment.

Moreover, the implication of this study dealt with: (1) the developed module will be effective is the teacher understand the implementation of case-based learning; (2) teachers should have holistic knowledge on the material so they could give confirmation on students' understanding; (3) teachers should have be able to explore updated issues and use it as topic of discussion; (4) learning facilities are important to provoke the learning process.

\section{CONCLUSION}

From the findings and discussion of the study, it can be concluded that: (1) the validity test on the development of case-based learning oriented Biology learning module was categorized as valid with average score 4,3 ; (2) the case-based learning oriented Biology learning module was categorized as practical with the average score of feasibility from six meetings was 4,25 , average score for teacher's attitude toward the developed module was 4,3 (very practical), and the average score for students' attitude toward the developed module was 4,12 (practical); (3) the case-based learning oriented Biology learning module was effective to improve students' critical thinking, it was showed by the average score of students' test result which was 86.68 and exceeded the passing grade and the t-test result with $\mathrm{p}$ value $<0,05$.

In accordance with the weaknesses of the development of this learning module due to the limitation on time to do the study, the next study on developing case-based learning Biology module is suggested to improve the substance as well as the design and use it as reference to do an experimental research.

\section{REFERENCES}

[1] Turer, B. \& Kunt,H.2015. A Review of Relationship between Prospective Science Teachers' Attitudes towards Science Education and Their SelfEfficacy. Journal of Education and Training Studies, 3(6) : 166-178

[2] Frederiksen, N. 1984. The Real Test Bias : Influencing of Testing on Teaching and Learning. American Psychologist Journal, 39 (3) : 1-8

[3] Mulyana,S \& Hartati,S.2009. Tinjauan Singkat Perkembangan CaseBased Reasoning. Seminar Nasional Informatika 2009 (Semnasif 2009) Upn "Veteran" Yogyakarta, 23 Mei 2009. Can be retrieve at Journal.Uinsgd.Ac.Id/Index.Php/Istek Accesed on December 42016

[4] Wood,A,.Carol,A. 2001. The Case Study Method: Critical Thinking Enhanced by Effective Teacher Questioning Skills. ERIC. 12(1): 1-12

[5] Rybarczyk,B.J., Baines,A.T., Mcvey.M., Thompson,J.T.,Willkins,H. 2006. A Case-Based Approach Increases Student Learning Outcomes And Comprehension Of Cellular Respiration Concepts. Biochemistry And Molecular Biology Education,35 (3) : 181-186 
[6] Thiagarajan, S; Semmel, D.S; \& Semmel, M.I. 1974. Instructional Development for Training Teachers of Exceptional Children: A Sourcebook. Indiana: Indiana University.

[7] Sugiyono. 2005. Statistika Untuk Penelitian. Bandung: Alfabeta.

[8] Wijaya, I.M.T.S. 2015. Pengembangan Modul Pembelajaran Biologi dengan Setting
Kooperatif Group Investigation.

[9] Susandari. 2012. Pengaruh Metoda Case- Based pada Pemahaman Konsep dan teori Psikologi Pendidikan. Prosiding SNaPP: Sosial, Ekonomi, dan Humaniora 3

(1),

361-366 